\title{
Antimicrobial and antiurease activities of newly synthesized morpholine derivatives containing an azole nucleus
}

\author{
Hakan Bektaş • Şule Ceylan • Neslihan Demirbaş • \\ Şengül Alpay-Karaoğlu • Bahar Bilgin Sökmen
}

Received: 24 June 2012/ Accepted: 25 October 2012/Published online: 29 November 2012

(C) The Author(s) 2012. This article is published with open access at Springerlink.com

\begin{abstract}
Morpholin-4-yl)pyridin-3-ylamino]acetohydrazide (4) was obtained starting from 6-morpholin-4ylpyridin-3-amine (2) via the formation of ester (3) and then converted to the corresponding Schiff bases $(\mathbf{5}, \mathbf{6})$ with the reaction with aromatic aldehydes. The carbothioamide (9), obtained from the reaction of hydrazide with phenylisothiocyanate, was converted to the corresponding 1,2,4-triazole (11) and 1,3,4-thiadiazole (12) derivatives by the treatment with $\mathrm{NaOH}$ or $\mathrm{H}_{2} \mathrm{SO}_{4}$, respectively. The cyclocondenzation of 9 with 4-chlorophenacyl bromide or ethyl bromoacetate produced the corresponding 1,3-thiazole (10) or 1,3-thiazolidine derivatives (13), respectively. Antimicrobial and antiurease activities of newly synthesized compounds were investigated. Some of them were found to be active on M. smegmatis, and they displayed activity toward C. albicans and S. cerevisiae in high concentration. Compound $\mathbf{1 0}$ proved to be the most potent showing an enzyme inhibition activity with an $\mathrm{IC}_{50}=2.37 \pm 0.19 \mu \mathrm{M}$.
\end{abstract}

H. Bektaş $(\bowtie) \cdot$ B. B. Sökmen

Department of Chemistry, Faculty of Arts and Sciences, Giresun University, 28049 Giresun, Turkey

e-mail: hakanbe_28@hotmail.com

Ş. Ceylan

Department of Forest Industry Engineering, Faculty of Forest, Artvin Coruh University, 08100 Artvin, Turkey

\section{N. Demirbaş}

Department of Chemistry, Faculty of Sciences, Karadeniz

Technical University, 61080 Trabzon, Turkey

Ş. Alpay-Karaoğlu

Department of Biology, Faculty of Arts and Sciences,

Rize University, 53100 Rize, Turkey
Keywords Morpholine $\cdot 1,2,4$-Triazole . 1,3,4-Oxadiazole · Mannich base . Antimicrobial activity $\cdot$ Antiurease activity

\section{Introduction}

Urea amidohydrolases (ureases) have been known as a class of large heteropolymeric enzymes with the active site containing two nickel (II) atoms and to accelerate hydrolysis of urea to ammonia gas with the reaction rate at least $10^{14}$ over the spontaneous reaction. Ureases are widely distributed in nature and are found in a variety of plants, algae, fungi, and bacteria (Kot et al., 2010). Medically, bacterial ureases have been reported as important virulence factors implicated in the pathogenesis of many clinical conditions such as pyelonephritis, hepatic coma, peptic ulceration, and the formation of injection-induced urinary stones and stomach cancer. The catalytic mechanism of their action has been believed to be the same of all urease inhibitors in which the amino acid sequences of the active site are principally conserved (Xiao et al., 2010). The active site of the native enzyme binds three water molecules and a hydroxide ion bridged between two nickel ions (Bachmeier et al., 2002). In the course of enzymatic reaction, urea replaces these three water molecules and bridges the two metal ions. The surrounding by a hydrogen-bonding network strongly activates the inert urea molecule; it is subsequently attacked by the hydroxide ion, forming a tetrahedral transition state. As a result, ammonia is released from the active site followed by the negatively charged carbamate (Adil et al., 2011). The latter decomposes rapidly and spontaneously, yielding a second molecule of ammonia. The ammonia generated may cause 
disruption to several metabolic functions in a large number of animal tissues and organs (Adil et al., 2011).

Urease is also indispensable for colonization of human gastric mucosa by Helicobacter pylori. The ammonia produced has been shown to be toxic for various gastric cell lines. Furthermore, urease activity was proposed to damage the gastric epithelium via its interaction with the immune system by stimulating an oxidative burst in human neutrophils (Ito et al., 1998). $\mathrm{H}_{2} \mathrm{O}_{2}$ generated in this oxidative burst probably reacts with ammonia and chloride to yield the toxic monochloramine (Kot et al., 2010). Finally, the ammonia may reach the serum and contribute to symptoms of hepatic encephalopathy in patients suffering from cirrhosis. Apart from ammonia, the carbon dioxide generated by urea hydrolysis may play a significant role for survival of H. pylori in the gastric mucosa (Cobena et al., 2008; Miroslawa et al., 2010; Xiao et al., 2010; Khan et al., 2010a, b; Ito et al., 1998; Keri et al., 2002; Ashiralieva and Kleiner, 2003).

Moreover, urea constitutes the predominant source of nitrogen containing fertilizers used in agriculture, accounting for $50 \%$ of the total world fertilizer nitrogen consumption. However, the efficiency of urea is decreased by its hydrolysis with the enzyme urease to ammonia gas in soil. Besides the economic impact for farmers, $\mathrm{NH}_{3}$ lost to the atmosphere from applied urea causes eutrophication and acidification of natural ecosystems on a regional scale (Cobena et al., 2008).

Several classes of compounds have been reported as the agents having antiurease activity; among them hydroxamicacids are the best recognized urease inhibitors (Adil et al., 2011; Krajewska, 2009; Muri et al., 2003). Phosphoramidates, another class of antiurease agents, have been reported as the most potent compounds (Amtul et al., 2002; Kot et al., 2001). However, the teratogenicity of hydroxamicacid in rats and degradation of phosphoramidates at low pH (Adil et al., 2011, Domínguez et al., 2008; Kreybig et al., 1968) restrict their use as a drug in vivo. Another class of compounds showing enzyme's inhibitory activity is polyphenols such as gallocatechin that is a polyphenol extracted from green tea and quercetin, a naturally occurring flavonoid having anti-H. pylori activity (Matsubara et al., 2003; Shin et al., 2005).

In addition, some 1,2,4-triazoles, 1,3,4-oxadiazoles, and 1,3,4-thiadiazoles have also been reported as the compounds possessing antiurease activity (Amtul et al., 2004; Aktay et al., 2009; Bekircan et al., 2008). Recently, some complexes of Schiff bases with metal ions showed significant inhibitory activities against urease (Shi et al., 2007; You et al.,2010) along with other metal complexes (Cheng et al.,2009). However, owing to the presence of heavy metal atoms, these types of compounds can inflict toxic effects on human body (Duruibe et al., 2007); hence, such molecules cannot be used as drugs.
During the recent decades, the human population being afflicted with life-threatening infectious diseases caused by multidrug-resistant Gram-positive and Gram-negative pathogen bacteria has been increasing at an alarming lscale around the world as a result of antimicrobial resistance. In spite of the wide range of antimicrobial drugs with different mechanisms of action used for the treatment of microbial infections either alone or in combination and also the existence of many compounds used in different phases of clinical trials, microbial infections have been posing a worldwide problem. There is already evidence that antimicrobial resistance is associated with an increase in mortality (Bayrak et al., 2010a, b, 2009a, b; Demirbas et al., 2009). The growing number of reports of antibiotic resistance worldwide has led to fears that some lethal human pathogens, such as Mycobacterium tuberculosis, will soon become untreatable (Dye and Williams, 2009; Dye and Phill, 2006; Koca et al., 2005; Zalavadiya et al., 2009). Tuberculosis (TB) causes the death of approximately three million patients in the world every year. These numbers make TB one of the leading infectious causes of death, eclipsed only by AIDS. Synthetic drugs for treating TB have been available for over half a century, but incidences of the disease continue to be on the rise worldwide. The causative organism, Mycobacterium tuberculosis, is a tremendously successful colonizer of the human host and is estimated to have latently infected approximately one-third of humanity. A growing number of immunocompromised patients are attributed to cancer chemotherapy, organ transplantation, and HIV infection, which are the major factors contributing to this increase. Therefore, it is necessary to search for and synthesize new classes of antimicrobial compounds that are effective against pathogenic microorganisms that have developed resistance to the antibiotics (Dye and Williams, 2009; Dye and Phill, 2006; Koca et al., 2005; Zalavadiya et al., 2009; Bayrak et al., 2010a, b).

In the field of medicinal chemistry, azoles belong to a class of antimicrobial agents that are widely used and studied because of their safety profile and high therapeutic index. Ribavirin, rizatriptan, alprazolam, vorozole, letrozole, and anastrozole are the best examples of drugs containing 1,2,4-triazole moiety (Ashok et al., 2007; Rao et al., 2006; Hancu et al., 2007; Cai et al., 2007). Among azole-based drugs, conazoles, such as itraconazole, fluconazole, voriconazole, and ravuconazole constitute a major class being used for the treatment of fungal infections ( $\mathrm{Yu}$ et al., 2007; Gupta et al., 2007; Schiller and Fung, 2007).

Another important pharmacophore group is the morpholine nucleus incorporated in a wide variety of therapeutically important drugs, one of which is linezolid which belongs to the oxazolidinone class of antibiotics and is used for the treatment of infections caused by gram-positive bacteria (Wyrzykiewicz et al., 2006; Dixit et al., 2005; 
Raparti et al., 2009; Bektas et al., 2010, 2012; Bayrak et al., 2009a, b). In addition, 4-phenylmorpholine derivatives have been reported to possess antimicrobial, antiinflammatory, and central nervous system activities (Dixit et al., 2006), Oxazolidinones are a relatively new class of synthetic antibacterial agents, having a new mechanism of action that involves early inhibition of bacterial protein synthesis. This class of compounds is particularly active against gram-positive organisms. Oxazolidinones are thought not to be cross-resistant with other types of antibiotics because of their different action mechanisms, which include interaction with the bacterial ribosome to inhibit bacteria. (Zheng et al., 2010; Giera et al., 2006; Das et al., 2005; Gage et al., 2000; Cui et al., 2005). Hence, oxazolidinone class of antibacterial compounds attracted considerable attention of a number of research groups during the last decade to get more efficacious and less toxic drug (Srivastava et al., 2008).

Thiazolidinone derivatives have been further reported to possess diverse pharmacological properties, such as antibacterial, antifungal, anticonvulsant, anticancer, antituberculosis, and antihuman immunodeficiency virus type 1 (HIV-1) activities. Thiazolidinones are novel inhibitors of the bacterial enzyme MurB, a precursor acting during the biosynthesis of peptidoglycan as an essential component of the cell wall of both gram-positive and gramnegative bacteria. (Bonde and Gaikwad, 2004; Aridoss et al., 2007; Küçükgüzel et al., 2002; Capan et al., 1999; Barreca et al., 2001; Andres et al., 2000; El-Gaby et al., 2009)
The identification and synthesis of combinational chemotherapeutic drugs with different mechanisms of action and with few side effects are an important part of the efforts to overcome antimicrobial resistance (Bayrak et al., 2010a, b). A recent survey of novel small-molecule therapeutics has revealed that the majority of the drugs results from an analog-based approach and that their market share represents two-thirds of all drug sales (Vicini et al., 2008).

In the present study, as a part of our ongoing study on the synthesis of bioactive hybrid molecules, we aimed to obtain the far derivatives of linezolid. It was reported that SAR studies of linezolid demonstrated a high tolerance for structural variation at the 4-position of the phenyl ring (Weidner-Wells et al., 2002). In the structures of the newly synthesized compounds, the phenyl ring substituted by pyridine and oxazolidinone scaffold by other azole rings such as 1,3-thiazole, 1,3-thiazolidinone, 1,2,4-triazole, 1,3,4-thiadiazole, and 1,3,4-oxadiazole nucleus.

\section{Results and discussion}

The synthetic route for the newly synthesized compounds (3-13) is illustrated and outlined in Schemes 1 and 2.

The synthesis of compound $\mathbf{3}$ was performed from the reaction of ethyl bromoacetate with compound $\mathbf{2}$ that is available commercially. Then, compound $\mathbf{3}$ was converted to the corresponding hydrazide (4) by the treatment with hydrazine hydrate. The FT-IR and ${ }^{1} \mathrm{H}$ NMR spectra of compound $\mathbf{4}$ displayed signals pointing the presence of
Scheme 1 Synthetic pathway for the preparation of compounds 1-6. $i$ morpholine, ii $\mathrm{Pd} / \mathrm{C}$ catalyst, $\mathrm{H}_{2} \mathrm{NNH}_{2}$, iii $\mathrm{BrCH}_{2} \mathrm{CO}_{2} \mathrm{Et}$, iv $\mathrm{H}_{2} \mathrm{NNH}_{2}$, $v \mathrm{BrC}_{6} \mathrm{H}_{4} \mathrm{CHO}$, vi $\mathrm{C}_{6} \mathrm{H}_{5} \mathrm{CH}=\mathrm{CHCHO}$

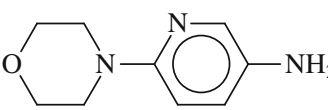

2

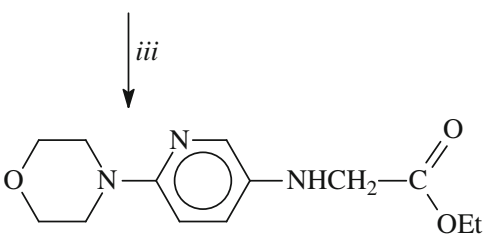

3<smiles>CC#CC1COCCN1c1ccc([N+](=O)[O-])cn1</smiles>

1

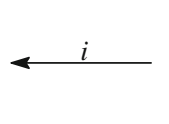<smiles>O=[N+]([O-])c1ccc(Cl)nc1</smiles>

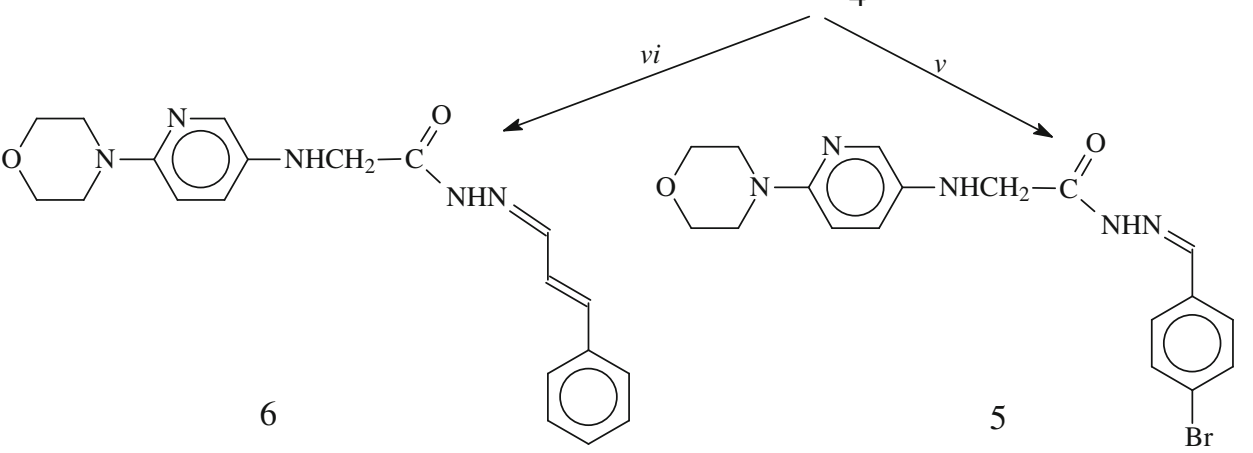


<smiles>CC#CCCNc1ccc(N2CCOCC2)nc1</smiles><smiles>CC(C)C</smiles>

8<smiles>NNC(=O)CNc1ccc(N2CCOCC2)nc1</smiles><smiles>C#CCCCC#N</smiles>

9<smiles>O=C(CNc1ccc(N2CCOCC2)nc1)NCC1CCCCC1</smiles>

10<smiles>NC(N)=S</smiles><smiles>CNc1ccccc1</smiles><smiles>CCCC=[Hg]</smiles><smiles>COC</smiles><smiles></smiles>

11<smiles>Cc1nnc(S)n1-c1ccccc1</smiles><smiles>C1CCCCC1</smiles><smiles>CC(C)Nc1nnc(CNc2ccc(N3CCOCC3)nc2)s1</smiles>

Scheme 2 Synthetic pathway for the preparation of compounds 7-13. $i \mathrm{CS}_{2} / \mathrm{KOH}$, ii phenyl piperazine, iii $\mathrm{PhNCS}$, iv $\mathrm{BrCH}_{2} \mathrm{COC}_{6} \mathrm{H}_{4}(4-)$, $v \mathrm{NaOH}$, vi $\mathrm{H}_{2} \mathrm{SO}_{4}$, vii $\mathrm{BrCH}_{2} \mathrm{CO}_{2} \mathrm{Et}$

hydrazide function, whereas the signals due to ester group disappeared in the NMR spectrum. The treatment of hydrazide, 4 with aromatic aldehydes, namely, 4-bromobenzaldehyde and cinnamaldehyde produced the corresponding Schiff bases, compounds 5 and $\mathbf{6}$. In the ${ }^{1} \mathrm{H}$ NMR spectra of these compounds, the signal derived from $\mathrm{NH}_{2}$ group disappeared; instead, new signals originated from aldehyde moiety were recorded at the related chemical shift values in the ${ }^{1} \mathrm{H}$ NMR and ${ }^{13} \mathrm{C}$ NMR spectra. Moreover, these compounds (5 and 6) exhibited EI-MS and elemental analysis data consistent with the proposed structures.

The synthesis of 5-\{[(6-morpholin-4-ylpyridin-3-yl)amino]methyl $\}-1,3,4$-oxadiazole-2-thiol (7) was carried out from the reaction of hydrazide $\mathbf{4}$ with carbon disulfide in the presence of potassium hydroxide. An evidence for the formation of $\mathbf{7}$ is the absence of the signals corresponding to hydrazide function in the FT-IR and ${ }^{1} \mathrm{H}$ NMR spectra. The $\mathrm{D}_{2} \mathrm{O}$ exchangeable signal observed at $13.45 \mathrm{ppm}$ was attributed to the SH proton located at the position-2 of 1,3,4oxadiazole ring. The reaction of $\mathbf{7}$ with phenylpiperazine in the presence of formaldehyde afforded the corresponding Mannich base, 5-\{[(6-morpholin-4-ylpyridin-3-yl) amino]methyl \}-3-[(4-phenylpiperazin-1-yl)methyl]-1,3,4-oxadiazole-2 $(3 H)$-thione $(\mathbf{8})$. In NMR spectra of $\mathbf{7}$, the presence of the peaks belonging to 4-phenylpiperazine nucleus confirmed the Mannich reaction.

The synthesis of $N^{\prime}$-[(5-(4-chlorophenyl)-3-phenyl-1, 3-thiazol-2(3H)-ylidene $\}-2-\{(6$-morpholin-4-ylpyridin3 -yl)amino acetohydrazide (10) obtained from the cyclocondenzation reaction between 4-chlorophenacyl bromide 
and compound 9 that was obtained by the treatment of hydrazide 4 with phenylisothiocyanate. On the other hand, the treatment of the same intermediate 9 with ethyl bromoacetate resulted in the formation of 2-[(6-morpholin4-ylpyridin-3-yl)amino]- $N^{\prime}$-(4-oxo-3-phenyl-1,3-thiazolidin2-ylidene)acetohydrazide 13. The structures of these compounds were confirmed on the basis of FT-IR, EI-MS, ${ }^{1} \mathrm{H}$ NMR, ${ }^{13} \mathrm{C}$ NMR spectroscopic methods, and elemental analysis.

The basic treatment of intermediate 9 afforded 5-[(6morpholin-4-ylpyridin-3-yl)methyl]-4-phenyl-4H-1,2,4triazole-3-thiol (11), while the cyclization of 9 in acidic media yielded 5-[(6-morpholin-4-ylpyridin-3-yl)methyl]$N$-phenyl-1,3,4-thiadiazol-2-amine (12). In the ${ }^{1} \mathrm{H}$ NMR spectrum of compound 11, the signal due to $\mathrm{SH}$ group was recorded at $13.91 \mathrm{ppm}$ as an evidence of intramolecular cyclization. This group was seen at $2,857 \mathrm{~cm}^{-1}$ in the FT-IR spectrum of compound 11. Two NH signals were recorded at 6.04 and $10.23 \mathrm{ppm}$ as $\mathrm{D}_{2} \mathrm{O}$ exchangeable peaks in the ${ }^{1} \mathrm{H}$ NMR spectrum of compound 12. In the ${ }^{13} \mathrm{C}$ NMR spectra of compounds 11 and 12, other signals belonging to 1,2,4-triazole or 1,3,4-thiadiazole nuclei resonated at the chemical shift values consistent with the literature (Bektas et al., 2010, 2012). Furthermore, [M] ${ }^{+}$ion peaks were observed at the related $m / z$ values supporting the proposed structures. In addition, these compounds gave reasonable elemental analysis data.

The newly synthesized compounds 3-13 were evaluated in vitro for their antimicrobial activities. The results are presented in the Table 1. Among the compounds tested, compound 8, which contains different heterocyclic moieties such as morpholine, pyridine, piperazine, and 1,3,4oxadiazole important antimicrobial activity, was found to be active against all the microorganisms. All compounds except compounds 6, 7, 10, and 13 exhibited activity toward Mycobacterium smegmatis (Ms), a nonpigmented, rapidly growing mycobacterium and an atypical tuberculosis factor leading to morbidity and mortality. The highest Ms activity with the MICvalue $15.6 \mu \mathrm{g} / \mathrm{mL}$ was observed for compound $\mathbf{1 2}$ that is a 1,2,4-triazole derivative containing morpholine and pyridine nuclei as well. All the tested compounds were found to be active on yeast like fungi, Candida albicans (Ca) and Saccharomyces cerevisiae $(\mathrm{Sc})$, in high concentrations with the MIC values of 500 or $1,000 \mu \mathrm{g} / \mathrm{mL}$, whereas all compounds, except compound $\mathbf{8}$, displayed no activity against gram-negative bacterial strain. In contrast to other compounds, compound 12 demonstrated a low activity against Pseudomonas aeruginosa $(\mathrm{Pa})$, a gram-negative bacillus.

Almost all the compounds showed moderate-to-good urease inhibitory activity (Table 2). The inhibition was increased with increasing compound concentration. Potent compound have their activities in the range of 2.37$13.23 \mu \mathrm{M}$. Lower $\mathrm{IC}_{50}$ values indicate higher enzyme inhibitor activity. Compound $\mathbf{1 0}$ proved to be the most potent showing an enzyme inhibition activity with an $\mathrm{IC}_{50}=2.37 \pm 0.19 \mu \mathrm{M}$. The least active compound 3 had an $\mathrm{IC}_{50}=13.23 \pm 2.25 \mu \mathrm{M}$.

Table 1 Antimicrobial activity of the compounds $(\mu \mathrm{g} / \mathrm{mL})$

\begin{tabular}{|c|c|c|c|c|c|c|c|c|c|}
\hline \multirow[t]{2}{*}{ Comp. no } & \multicolumn{9}{|c|}{ Microorganisms and minimal inhibition concentration } \\
\hline & Ec & Yp & $\mathrm{Pa}$ & Ef & $\mathrm{Sa}$ & $\mathrm{Bc}$ & Ms & $\mathrm{Ca}$ & Sc \\
\hline 3 & - & - & - & - & - & - & 125 & 1,000 & 1,000 \\
\hline 4 & - & - & - & - & - & - & 125 & 500 & 1,000 \\
\hline 5 & - & - & - & - & - & - & 31.3 & 1,000 & 1,000 \\
\hline 6 & - & - & - & - & - & - & - & 500 & 1,000 \\
\hline 7 & - & - & - & - & - & - & - & 500 & 1,000 \\
\hline 8 & 62.5 & 62.5 & 62.5 & 31.3 & 31.3 & 62.5 & 125 & 1,000 & 1,000 \\
\hline 9 & - & - & - & - & - & - & 125 & 1,000 & 1,000 \\
\hline 10 & - & - & - & - & - & - & - & 500 & 1,000 \\
\hline 11 & - & - & - & - & - & - & 125 & 500 & 1,000 \\
\hline 12 & - & - & 500 & - & - & - & 15.6 & 500 & 1,000 \\
\hline 13 & - & - & - & - & - & - & - & 500 & 1,000 \\
\hline Amp. & 8 & 32 & $>128$ & 2 & 2 & $<1$ & & & \\
\hline Str. & & & & & & & 4 & & \\
\hline Flu. & & & & & & & & $<8$ & $<8$ \\
\hline
\end{tabular}

Ec: Escherichia coli ATCC 25922, Yp: Yersinia pseudotuberculosis ATCC 911, Pa: Pseudomonas aeruginosa ATCC 43288, Ef: Enterococcus faecalis ATCC 29212, Sa: Staphylococcus aureus ATCC 25923, Bc: Bacillus cereus 702 Roma, Ms: Mycobacterium smegmatis ATCC 607, Ca: Candida albicans ATCC 60193, Sc: S. cerevisiae RSKK 251, Amp.: Ampicillin, Str.: Streptomisin, Flu.: Fluconazole 
Table 2 The urease inhibitory activity of different concentrations of morpholin derivatives

\begin{tabular}{lr}
\hline Compounds & $\mathrm{IC}_{50}(\mu \mathrm{M})^{\mathrm{a}}$ \\
\hline $\mathbf{3}$ & $13.23 \pm 2.25$ \\
$\mathbf{4}$ & $7.92 \pm 1.43$ \\
$\mathbf{5}$ & $6.87 \pm 0.06$ \\
$\mathbf{6}$ & $8.29 \pm 2.30$ \\
$\mathbf{7}$ & $7.01 \pm 0.68$ \\
$\mathbf{8}$ & $4.99 \pm 0.59$ \\
$\mathbf{9}$ & $8.07 \pm 1.25$ \\
$\mathbf{1 0}$ & $2.37 \pm 0.19$ \\
$\mathbf{1 1}$ & $4.77 \pm 0.92$ \\
$\mathbf{1 2}$ & $6.05 \pm 1.19$ \\
$\mathbf{1 3}$ & $4.46 \pm 0.22$ \\
\hline
\end{tabular}

${ }^{\text {a }}$ Mean \pm SD

\section{Conclusion}

In this study, the synthesis of some morpholine derivatives (3-13) were performed, some of which contain an azole moiety, and their structures were confirmed by IR, ${ }^{1} \mathrm{H}$ NMR, ${ }^{13} \mathrm{C}$ NMR, Mass spectroscopic, and elemental analysis techniques. In addition, the newly synthesized compounds were screened for their antimicrobial and antiurease activities. Some of them were found to possess activity on $M$. smegmatis, $C$. albicans ATCC, and $S$. cerevisiae. Furthermore, all the compounds exhibited moderate-to-good antiurease activity

\section{Experimental}

\section{Chemistry}

\section{General information for chemicals}

All the chemicals were purchased from Fluka Chemie AG Buchs (Switzerland) and used without further purification. Melting points of the synthesized compounds were determined in open capillaries on a Büchi B-540 melting point apparatus and are uncorrected. Reactions were monitored by thin-layer chromatography (TLC) on silica gel 60 F254 aluminum sheets. The mobile phase was ethanol:ethyl acetate, $1: 1$, and detection was made using UV light. FT-IR spectra were recorded as potassium bromide pellets using a Perkine Elmer 1600 series FTIR spectrometer. ${ }^{1} \mathrm{H}$ NMR and ${ }^{13} \mathrm{C}$ NMR spectra were registered on DMSO- $d_{6}$ on a BRUKER AVENE II $400 \mathrm{MHz}$ NMR Spectrometer (400.13 MHz for ${ }^{1} \mathrm{H}$ and $100.62 \mathrm{MHz}$ for ${ }^{13} \mathrm{C}$ ). The chemical shifts are given in ppm relative to $\mathrm{Me}_{4} \mathrm{Si}$ as an internal reference; $J$ values are given in Hz. The elemental analysis was performed on $a$
Costech Elemental Combustion System CHNS-O elemental analyzer. All the compounds gave $\mathrm{C}, \mathrm{H}$, and $\mathrm{N}$ analysis results within $\pm 0.4 \%$ of the theoretical values. The mass spectra were obtained on a Quattro $L C-M S(70 \mathrm{eV})$ Instrument. Compounds $\mathbf{1}$ and $\mathbf{2}$ are available commercially.

\section{Synthesis of compound $\mathbf{3}$}

Ethylbromoacetate $(10 \mathrm{mmol})$ was added to the mixture of compound 2 (10 mmol), and triethylamine (10 mmol) was added dropwise in dry tetrahydrofurane at $0-5{ }^{\circ} \mathrm{C}$. Then, the reaction content was allowed to reach to room temperature and stirred for $11 \mathrm{~h}$ (the progress of the reaction was monitored by TLC). The precipitated triethylammonium salt was removed by filtration. After evaporating the solvent under reduced pressure, a brown solid appeared. This crude product was recrystallized from ethanol-water (1:2) to afford the desired product.

\section{Ethyl N-(6-morpholin-4-ylpyridin-3-yl)glycinate (2)}

Yield (1.27 g, $50 \%)$; m.p. $83-84{ }^{\circ} \mathrm{C}$; IR $\left(\mathrm{KBr}, \mathrm{v}, \mathrm{cm}^{-1}\right)$ : $3,378(\mathrm{NH}), 1,725(\mathrm{C}=\mathrm{O}), 1,575(\mathrm{C}=\mathrm{N}), 1,118(\mathrm{C}-\mathrm{O}) ;{ }^{1} \mathrm{H}$ NMR (DMSO- $\left.d_{6}, \delta \mathrm{ppm}\right): 1.17\left(\mathrm{t}, 3 \mathrm{H}, \mathrm{CH}_{3}, J=7.4 \mathrm{~Hz}\right)$, $3.18\left(\mathrm{t}, 4 \mathrm{H}, 2 \mathrm{NCH}_{2}, J=4.8 \mathrm{~Hz}\right), 3.69\left(\mathrm{t}, 4 \mathrm{H}, 2 \mathrm{OCH}_{2}\right.$, $J=4.4 \mathrm{~Hz}), 3.84\left(\mathrm{~d}, 2 \mathrm{H}, \mathrm{NHCH}_{2}, J=6.4 \mathrm{~Hz}\right), 4.08(\mathrm{q}$, $\left.2 \mathrm{H}, \mathrm{OCH}_{2} \mathrm{CH}_{3}, J=7 \mathrm{~Hz}\right), 5.57(\mathrm{t}, 1 \mathrm{H}, \mathrm{NH}, J=6.8 \mathrm{~Hz})$, $6.67(\mathrm{~d}, 1 \mathrm{H}, \operatorname{arH}, J=9 \mathrm{~Hz}), 6.92-6.98(\mathrm{~m}, 1 \mathrm{H}, \operatorname{arH}), 7.56$ $(\mathrm{d}, 1 \mathrm{H}, \operatorname{arH}, J=2.4 \mathrm{~Hz}) ;{ }^{13} \mathrm{C}$ NMR (DMSO- $\left.d_{6}, \delta \mathrm{ppm}\right)$ : $14.83\left(\mathrm{CH}_{3}\right), 45.84\left(\mathrm{NHCH}_{2}\right), 47.40\left(2 \mathrm{NCH}_{2}\right), 60.94$ $\left(\underline{\mathrm{CH}_{2}} \mathrm{OCH}_{3}\right), 66.74\left(2 \mathrm{OCH}_{2}\right), \operatorname{arC}:[108.94(\mathrm{CH}), 123.74$ $(\overline{\mathrm{CH}}), 132.35(\mathrm{CH}), 138.22(\mathrm{C}), 153.34(\mathrm{C})], 172.08$ $(\mathrm{C}=\mathrm{O})$; LC-MS: $\mathrm{m} / \mathrm{z}$ (\%) $266.257[\mathrm{M}+1]^{+}(85), 164.12$ (94); Anal.calcd (\%) for $\mathrm{C}_{13} \mathrm{H}_{19} \mathrm{~N}_{3} \mathrm{O}_{3}$ : C, 58.85; H, 7.22; N, 15.84. Found: C, 58.65; H, 7.28; N, 15.85 .

Synthesis of compound 4

Hydrazide hydrate $(25 \mathrm{mmol})$ was added to the solution of compound 2 (10 mmol) in absolute ethanol, and the mixture was allowed to reflux for $7 \mathrm{~h}$. On cooling the reaction mixture to room temperature, a white solid appeared. The crude product was filtered off and recrystallized from ethanol to give the desired compound 4 .

\section{2-[6-(Morpholin-4-yl)pyridin-3-ylamino Jacetohydrazide (4)}

Yield (2.23 g, $89 \%$ ); m.p. $175-177{ }^{\circ} \mathrm{C}$; IR (KBr, v, $\left.\mathrm{cm}^{-1}\right)$ : 3341, 3301, $3189\left(\mathrm{NH}_{2}+\mathrm{NH}\right), 1,658(\mathrm{C}=\mathrm{O}), 1,578(\mathrm{C}=\mathrm{N})$, $1,118(\mathrm{C}-\mathrm{O}) ;{ }^{1} \mathrm{H}$ NMR (DMSO- $\left.d_{6}, \delta \mathrm{ppm}\right): 3.14(\mathrm{t}, 4 \mathrm{H}, \mathrm{N}-$ $\left.2 \mathrm{CH}_{2}, J=4.8 \mathrm{~Hz}\right), 3.77\left(\mathrm{t}, 4 \mathrm{H}, \mathrm{O}-2 \mathrm{CH}_{2}, J=4.8 \mathrm{~Hz}\right)$, $4.00\left(\mathrm{~d}, 2 \mathrm{H}, \mathrm{N}-\mathrm{CH}_{2}, J=6.4 \mathrm{~Hz}\right), 4.22\left(\mathrm{~s}, 2 \mathrm{H}, \mathrm{NH}_{2}\right), 5.42$ 
$(\mathrm{s}, 1 \mathrm{H}, \mathrm{NH}), 5.57(\mathrm{t}, 1 \mathrm{H}, \mathrm{NH}, J=6.8 \mathrm{~Hz}), 6.65(\mathrm{~d}, 1 \mathrm{H}$, $\operatorname{arH}, J=8.4 \mathrm{~Hz}), 6.94(\mathrm{~m}, 1 \mathrm{H}, \operatorname{arH}), 7.56(\mathrm{~s}, 1 \mathrm{H}, \operatorname{arH}) ;{ }^{13} \mathrm{C}$ NMR (DMSO- $d_{6}, \delta$ ppm): $45.22\left(\mathrm{CH}_{2}\right), 47.42\left(\mathrm{~N}-2 \mathrm{CH}_{2}\right)$, $66.73\left(\mathrm{O}-2 \mathrm{CH}_{2}\right), \operatorname{arC}$ : [108.99 $(\mathrm{CH}), 123.83(\mathrm{CH}), 132.36$ $(\mathrm{CH}), 138.70(\mathrm{C}), 151.71(\mathrm{C})], 172.20(\mathrm{C}=\mathrm{O})$; LC-MS: $\mathrm{m} / \mathrm{z}$ (\%) $252.29[\mathrm{M}+1]^{+}(80), 164.12$ (90); Anal.calcd (\%) for $\mathrm{C}_{11} \mathrm{H}_{17} \mathrm{~N}_{5} \mathrm{O}_{2}$ : $\mathrm{C}, 52.58 ; \mathrm{H}, 6.82 ; \mathrm{N}, 27.87$. Found: $\mathrm{C}$, $52.55 ; \mathrm{H}, 6.68 ; \mathrm{N}, 27.95$.

Syntheses of compounds 5 and $\mathbf{6}$

The solution of compound $4(10 \mathrm{mmol})$ in absolute ethanol was refluxed with appropriate aldehyde $(10 \mathrm{mmol})$ for $6 \mathrm{~h}$. Then, the reaction content was allowed to cool to room temperature, and a solid appeared. This crude product was filtered off and recrystallized from ethanol to obtain the desired compound.

$N$-(4-Bromobenzylidene)-2-[6-(morpholin-4-yl)pyridin3-ylamino]acetohydrazide (5)

Yield (3.43 g, $82 \%$ ); m.p. $163-164{ }^{\circ} \mathrm{C}$; IR $\left(\mathrm{KBr}, \mathrm{v}, \mathrm{cm}^{-1}\right)$ : 3,307 (2NH), 1,687 (C=O), 1,590 (C=N), 1,121 (C-O); ${ }^{1} \mathrm{H}$ NMR (DMSO- $d_{6}, \delta$ ppm): 3.20 (brs, $4 \mathrm{H}, \mathrm{N}-2 \mathrm{CH}_{2}$ ), 3.73 (brs, $\left.4 \mathrm{H}, \mathrm{O}-2 \mathrm{CH}_{2}\right), 4.20$ (brs, $\left.2 \mathrm{H}, \mathrm{CH}_{2}\right), 6.73(\mathrm{~d}, 1 \mathrm{H}, \operatorname{arH}$, $J=8.6 \mathrm{~Hz}), 6.99-7.12(\mathrm{~m}, 1 \mathrm{H}, \mathrm{NH}), 7.60(\mathrm{~d}, 6 \mathrm{H}, \operatorname{arH}$, $J=6.2 \mathrm{~Hz}), 8.91(\mathrm{~s}, 1 \mathrm{H}, \mathrm{N}=\mathrm{CH}), 11.58(\mathrm{~s}, 1 \mathrm{H}, \mathrm{NH}) ;{ }^{13} \mathrm{C}$ NMR (DMSO- $d_{6}, \delta$ ppm): $45.93\left(\mathrm{CH}_{2}\right), 56.72\left(\mathrm{~N}-2 \mathrm{CH}_{2}\right)$, $66.61\left(\mathrm{O}-2 \mathrm{CH}_{2}\right)$, arC: [123.20 (C), $124.90(\mathrm{C}), 129.66$ $(\mathrm{CH}), 130.01(\mathrm{CH}), 130.73(\mathrm{CH}), 130.98(2 \mathrm{CH}), 132.51$ $(2 \mathrm{CH}), 136.25(\mathrm{C}), 138.16(\mathrm{C})], 132.62(\mathrm{~N}=\mathrm{CH}), 166.12$ $(\mathrm{C}=\mathrm{O})$; LC-MS: $\mathrm{m} / \mathrm{z}(\%) 418.66[\mathrm{M}]^{+}$(78), $265.12(28)$; Anal.calcd (\%) for $\mathrm{C}_{18} \mathrm{H}_{20} \mathrm{BrN}_{5} \mathrm{O}_{2}: \mathrm{C}, 51.69 ; \mathrm{H}, 4.82 ; \mathrm{N}$, 16.74. Found: C, 51.60; H, 4.75; N, 16.80.

\section{2-\{[6-(Morpholin-4-yl)pyridin-3-yl]amino\}-N-(3- phenylallylidene)acetohydrazide (6)}

Yield (3.18 g, 87 \%); m.p. $194-195{ }^{\circ} \mathrm{C}$; IR $\left(\mathrm{KBr}, \mathrm{v}, \mathrm{cm}^{-1}\right)$ : 3,208 (2NH), 1,666 $(\mathrm{C}=\mathrm{O}), 1,554(\mathrm{C}=\mathrm{N}), 1,120(\mathrm{C}-\mathrm{O}) ;{ }^{1} \mathrm{H}$ NMR (DMSO- $d_{6}, \delta$ ppm): 3.19 (brs, $4 \mathrm{H}, \mathrm{N}-2 \mathrm{CH}_{2}$ ), 3.67 (brs, $\left.4 \mathrm{H}, \mathrm{O}-2 \mathrm{CH}_{2}\right), 4.08\left(\mathrm{~d}, 2 \mathrm{H}, \mathrm{CH}_{2}, J=5.2 \mathrm{~Hz}\right), 5.46$ (s, $1 \mathrm{H}, \mathrm{CH}), 6.69(\mathrm{~d}, 1 \mathrm{H}, \mathrm{CH}, J=8.2 \mathrm{~Hz}), 6.99(\mathrm{~d}, 3 \mathrm{H}$, $\operatorname{arH}+\mathrm{NH}, J=3.2 \mathrm{~Hz}), 7.35(\mathrm{~d}, 3 \mathrm{H}, \operatorname{arH}, J=7.4 \mathrm{~Hz}), 7.61$ (brs, 3H, arH), $7.91(\mathrm{~s}, 1 \mathrm{H}, \mathrm{NH}), 11.42(\mathrm{~s}, 1 \mathrm{H}, \mathrm{NH}) ;{ }^{13} \mathrm{C}$ NMR (DMSO- $d_{6}, \delta$ ppm): $47.48\left(\mathrm{CH}_{2}\right), 56.72\left(\mathrm{~N}-2 \mathrm{CH}_{2}\right)$, $66.75\left(\mathrm{O}-2 \mathrm{CH}_{2}\right), \operatorname{arC}:[125.83(\mathrm{CH}), 126.20(\mathrm{CH}), 127.76$ $(\mathrm{CH}), 129.53(\mathrm{CH}), 132.51(\mathrm{CH}), 136.56(\mathrm{C}), 138.42(\mathrm{CH})$, $139.62(\mathrm{CH}), 146.75(\mathrm{CH}), 153.22(\mathrm{C}), 167.52(\mathrm{C})], 108.98$ $(\mathrm{CH}), 123.84(\mathrm{CH}), 149.48(\mathrm{~N}=\mathrm{CH}), 172.00(\mathrm{C}=\mathrm{O})$; LCMS: $m / z(\%) 365.66[\mathrm{M}]^{+}$(75), $265.46(56), 165.23$ (90); Anal.calcd (\%) for $\mathrm{C}_{20} \mathrm{H}_{23} \mathrm{~N}_{5} \mathrm{O}_{2}: \mathrm{C}, 65.74 ; \mathrm{H}, 6.34 ; \mathrm{N}$, 19.16. Found: C, 65.82; H, 6.36; N, 19.22.
Synthesis of compound 7

Compound $4(10 \mathrm{mmol})$ and $\mathrm{CS}_{2}(6.0 \mathrm{~mL}, 10 \mathrm{~mol})$ were added to a solution of $\mathrm{KOH}(0.56 \mathrm{~g}, 10 \mathrm{~mol})$ in $50 \mathrm{~mL}$ $\mathrm{H}_{2} \mathrm{O}$ and $50 \mathrm{~mL}$ ethanol. The reaction mixture was refluxed for $3 \mathrm{~h}$. After evaporating in reduced pressure to dryness, a solid was obtained. This was dissolved in $300 \mathrm{~mL} \mathrm{H}_{2} \mathrm{O}$ and acidified with conc. $\mathrm{HCl}$. The precipitate was filtered off, washed with $\mathrm{H}_{2} \mathrm{O}$, and recrystallized from ethanol to afford the desired compound.

\section{5-\{[(6-Morpholin-4-ylpyridin-3-yl)amino]methyl\}-} 1,3,4-oxadiazole-2-thiol (7)

Yield (2.08 g, $71 \%)$; m.p. $221-222{ }^{\circ} \mathrm{C}$; IR $\left(\mathrm{KBr}, \mathrm{v}, \mathrm{cm}^{-1}\right)$ : 3,299 (NH), 3,071 (Ar CH), 1,535 (C=N), 1,118 (C-O); ${ }^{1} \mathrm{H}$ NMR (DMSO- $\left.d_{6}, \delta \mathrm{ppm}\right): 3.20\left(\mathrm{~s}, 4 \mathrm{H}, \mathrm{N}-2 \mathrm{CH}_{2}\right), 3.67(\mathrm{~s}$, $4 \mathrm{H}, \mathrm{O}-2 \mathrm{CH}_{2}$ ), 4.35 (brs, $2 \mathrm{H}, \mathrm{CH}_{2}$ ), 5.94 (bs, $\left.1 \mathrm{H}, \mathrm{NH}\right), 6.71$ $(\mathrm{d}, 1 \mathrm{H}, \operatorname{arH}, J=7.4 \mathrm{~Hz}), 7.04(\mathrm{~d}, 1 \mathrm{H}, \operatorname{arH}, J=9 \mathrm{~Hz})$, 7.67 (s, $1 \mathrm{H}, \operatorname{arH}), 13.45$ (s, 1H, SH) ${ }^{13} \mathrm{C}$ NMR (DMSO- $d_{6}$, $\delta$ ppm): $38.44-41.36$ (DMSO- $\left.d_{6}+\mathrm{CH}_{2}\right), 47.15\left(\mathrm{~N}-2 \mathrm{CH}_{2}\right)$, $66.67\left(\mathrm{O}-2 \mathrm{CH}_{2}\right), \operatorname{arC}:[109.22(\mathrm{CH}), 124.70(\mathrm{CH}), 132.04$ $(\mathrm{CH}), 137.20(\mathrm{C}), 150.45(\mathrm{C})], 163.10$ (oxadiazole C-2), 178.54 (oxadiazole C-5); LC-MS: $m / z$ (\%) $293.45[\mathrm{M}]^{+}$ (45), $294.75[\mathrm{M}+1]^{+}$(86), 165.23 (35); Anal.calcd (\%) for $\mathrm{C}_{12} \mathrm{H}_{15} \mathrm{~N}_{5} \mathrm{O}_{2} \mathrm{~S}: \mathrm{C}, 49.13 ; \mathrm{H}, 5.15 ; \mathrm{N}, 23.87, \mathrm{~S}, 10.93$. Found: C, 49.25; H, 5.10; N, 23.90; S, 10.85 .

\section{Synthesis of compound $\mathbf{8}$}

To the solution of corresponding compound $7(10 \mathrm{mmol})$ in dichloromethane, formaldehyde $(37 \%, 1.55 \mathrm{~mL})$ and phenyl piperazine $(10 \mathrm{mmol})$ were added, and the mixture was stirred at room temperature for $3 \mathrm{~h}$. After removing the solvent under reduced pressure, a solid was obtained. This crude product was treated with water, filtered off, and recrystallized from ethyl acetate/petroleum ether (1:2) to yield the desired compound.

5-\{[(6-Morpholin-4-ylpyridin-3-yl)amino]methyl\}-3-[(4phenylpiperazin-1-yl)methyl]-1,3,4-oxadiazole-2(3H)thione (8)

Yield $(3.79 \mathrm{~g}, 81 \%)$; m.p. $87-88^{\circ} \mathrm{C}$; IR $\left(\mathrm{KBr}, \mathrm{v}, \mathrm{cm}^{-1}\right)$ : 3,392 (NH), 1,599 (C=N), 1,118 (C-O); ${ }^{1} \mathrm{H}$ NMR (DMSO$d_{6}, \delta \mathrm{ppm}$ ): 3.14 (s, 4H, N-2CH2), 3.79 (s, 4H, O-2CH2), 4.51 (brs, 2H, CH2), 4.86 (bs, $8 \mathrm{H}, 4 \mathrm{CH} 2), 5.01$ (s, $2 \mathrm{H}$, $\mathrm{CH} 2), 5.43$ (bs, 1H, NH), $6.61(\mathrm{~m}, 1 \mathrm{H}, \mathrm{arH}), 6.90(\mathrm{~m}, 3 \mathrm{H}$, arH), $7.26(\mathrm{~m}, 3 \mathrm{H}, \operatorname{arH}), 8.03(\mathrm{~m}, 1 \mathrm{H}, \operatorname{arH}) ;{ }^{13} \mathrm{C}$ NMR (DMSO- $d_{6}, \delta$ ppm): 46.33(N-CH $\left.\mathrm{CH}_{2}\right), 46.54\left(\mathrm{~N}-\mathrm{CH}_{2}\right), 49.52$ $\left(\mathrm{N}-2 \mathrm{CH}_{2}\right), 50.16\left(\mathrm{~N}-\mathrm{CH}_{2}\right), 50.59\left(\mathrm{~N}-\mathrm{CH}_{2}\right), 66.97(\mathrm{O}-$ $\left.2 \mathrm{CH}_{2}\right), 70.28\left(2 \mathrm{CH}_{2}\right)$, arC: [107.98 $(\mathrm{CH}), 116.64(2 \mathrm{CH})$, $117.32(\mathrm{CH}), 120.39(\mathrm{CH}), 129.43(2 \mathrm{CH}), 133.42(\mathrm{C})$, 
$136.29(\mathrm{CH}), 151.39(\mathrm{C}), 156.61(\mathrm{C})], 173.47$ (oxadiazole C-2), 178.99 (oxadiazole C-5); LC-MS: $\mathrm{m} / \mathrm{z}$ (\%) 466.85 $[\mathrm{M}]^{+}(54), 468.11[\mathrm{M}+1]^{+}$(36), 215.45(55); Anal.calcd (\%) for $\mathrm{C} 23 \mathrm{H} 29 \mathrm{~N} 7 \mathrm{O} 2 \mathrm{~S}$ : C, 59.08; H, 6.25; N, 20.97, S, 6.86. Found: C, 59.18; H, 6.20; N, 20.82; S, 6.88 .

\section{Synthesis of compound 9}

The mixture of compound 4 (10 mmol) and phenylisothiocyanate $(10 \mathrm{mmol})$ in absolute ethanol was refluxed for $6 \mathrm{~h}$. On allowing the reaction content to be cooled to room temperature, a white solid was formed. This crude product was filtered off and recrystallized from ethylacetate to afford the desired compound.

\section{2-\{[(6-Morpholin-4-ylpyridin-3-yl)amino]acetyl $\}-N$ -} phenylhydrazinecarbothioamide (9)

Yield (3.16 g, $82 \%)$; m.p. $171-172{ }^{\circ} \mathrm{C}$; IR $\left(\mathrm{KBr}, v, \mathrm{~cm}^{-1}\right)$ : 3,321 (2NH), 3,164 (2NH), 1,685 (C=O), 1,215 (C=S), $1,110(\mathrm{C}-\mathrm{O}) ;{ }^{1} \mathrm{H}$ NMR (DMSO- $d_{6}, \delta \mathrm{ppm}$ ): 3.02 (bs, $4 \mathrm{H}$, $\left.\mathrm{N}-2 \mathrm{CH}_{2}\right), 3.58$ (bs, 4H, O-2 $\left.\mathrm{CH}_{2}\right), 3.82\left(\mathrm{~d}, 2 \mathrm{H}, \mathrm{CH}_{2}\right.$, $J=5.2 \mathrm{~Hz}), 5.85(\mathrm{~s}, 1 \mathrm{H}, \mathrm{NH}), 6.42-6.52(\mathrm{~m}, 2 \mathrm{H}, \operatorname{arH})$, $6.92(\mathrm{~d}, 2 \mathrm{H}, \quad \operatorname{arH}, J=9.8 \mathrm{~Hz}), 7.26(\mathrm{~d}, 2 \mathrm{H}, \quad \operatorname{arH}$, $J=9.4 \mathrm{~Hz}), 7.75(\mathrm{bs}, 2 \mathrm{H}, \mathrm{arH}), 9.55(\mathrm{~s}, 1 \mathrm{H}, \mathrm{NH}), 9.72(\mathrm{bs}$, $1 \mathrm{H}, \mathrm{NH}), 10.42(\mathrm{~s}, 1 \mathrm{H}, \mathrm{NH}) ;{ }^{13} \mathrm{C}$ NMR (DMSO- $d_{6}$, $\delta$ ppm): $45.32\left(\mathrm{CH}_{2}\right), 55.54\left(\mathrm{~N}-2 \mathrm{CH}_{2}\right), 66.35\left(\mathrm{O}-2 \mathrm{CH}_{2}\right)$, arC: $[101.52(\mathrm{CH}), 114.56(\mathrm{CH}), 125.83(\mathrm{CH}), 126.20$ $(\mathrm{CH}), 128.24(\mathrm{CH}), 132.51(\mathrm{CH}), 136.56(\mathrm{C}), 138.42(\mathrm{CH})$, $139.62(\mathrm{CH}), 146.75(\mathrm{C}), 153.22(\mathrm{C})], 170.56(\mathrm{C}=\mathrm{O})$, $182.23(\mathrm{C}=\mathrm{S})$; LC-MS: $m / z$ (\%) $386.25 \mathrm{[M}^{+}{ }^{(68),} 265.24$ (66), 165.85 (87); Anal.calcd (\%) for $\mathrm{C}_{18} \mathrm{H}_{22} \mathrm{~N}_{6} \mathrm{O}_{2} \mathrm{~S}: \mathrm{C}$, 55.94; H, 5.74; N, 21.75; S, 8.30. Found: C, 55.82; H, 5.82; $\mathrm{N}, 21.62 ; \mathrm{S}, 8.42$.

\section{Synthesis of compound $\mathbf{1 0}$}

4-Chlorophenacylbromide $(10 \mathrm{mmol})$ and dried sodium acetate $(16.4 \mathrm{~g} 200 \mathrm{mmol})$ was added to the solution of compound 9 in absolute ethanol, and the reaction mixture was refluxed for $7 \mathrm{~h}$. Then, the mixture was cooled to room temperature, poured into ice-cold water under stirring, and left overnight in cold. The formed solid was filtered, washed with water three times and recrystallized from ethanol to afford compound $\mathbf{1 0 .}$

$N^{\prime}$-[(5-(4-Chlorophenyl)-3-phenyl-1,3-thiazol-2(3H)ylidene $-2-\{(6-$ morpholin-4-ylpyridin-3-

yl)amino\}acetohydrazide (10)

Yield (3.33 g, $64 \%)$; m.p. $168-169{ }^{\circ} \mathrm{C}$; IR $\left(\mathrm{KBr}, \mathrm{v}, \mathrm{cm}^{-1}\right)$ : $3,283(2 \mathrm{NH}), 1,699(\mathrm{C}=\mathrm{O}), 1,588(\mathrm{C}=\mathrm{N}), 1,116(\mathrm{C}-\mathrm{O}) ;{ }^{1} \mathrm{H}$ NMR (DMSO- $d_{6}, \delta$ ppm): 3.34 (bs, $4 \mathrm{H}, \mathrm{N}-2 \mathrm{CH}_{2}$ ), 3.81 (d, $\left.4 \mathrm{H}, \mathrm{O}-2 \mathrm{CH}_{2}, J=4.8 \mathrm{~Hz}\right), 4.87\left(\mathrm{~s}, 2 \mathrm{H}, \mathrm{CH}_{2}\right), 5.65(\mathrm{~s}, 1 \mathrm{H}$, $\mathrm{NH}), 6.57(\mathrm{~d}, 1 \mathrm{H}, \mathrm{CH}, J=8.6 \mathrm{~Hz}), 7.31(\mathrm{~m}, 3 \mathrm{H}, \operatorname{arH})$, 7.44-7.57 (m, 6H, arH), $7.97(\mathrm{~d}, 3 \mathrm{H}, \operatorname{arH}, J=8.6 \mathrm{~Hz})$, $10.54(\mathrm{~s}, 1 \mathrm{H}, \mathrm{NH}) ;{ }^{13} \mathrm{C}$ NMR (DMSO- $\left.d_{6}, \delta \mathrm{ppm}\right): 41.19$ $\left(\mathrm{CH}_{2}\right), 47.15\left(\mathrm{~N}-2 \mathrm{CH}_{2}\right), 66.99\left(\mathrm{O}-2 \mathrm{CH}_{2}\right)$, arC: [126.99 $(2 \mathrm{CH}), 129.47(2 \mathrm{CH}), 130.21(2 \mathrm{CH}), 130.57(2 \mathrm{CH}), 130.84$ $(2 \mathrm{CH}), 135.64(2 \mathrm{C}), 134.05(2 \mathrm{CH}), 136.24(2 \mathrm{C}), 140.82$ (C)], $125.83(\mathrm{CH}$, tiyazol C-4), 152.30 (tiyazol C-2), 153.84 (tiyazol C-5), $192.20(\mathrm{C}=\mathrm{O})$; LC-MS: $\mathrm{m} / \mathrm{z}(\%)$ $521.25[\mathrm{M}]^{+}$(45), 215.45 (65), 165.45 (75); Anal.calcd (\%) for $\mathrm{C}_{26} \mathrm{H}_{25} \mathrm{ClN}_{6} \mathrm{O}_{2} \mathrm{~S}$ : C, 59.94; $\mathrm{H}, 4.84 ; \mathrm{N}, 16.13, \mathrm{~S}$, 6.15. Found: C, 59.85; H, 4.78; N, 16.22; S, 6.18.

\section{Synthesis of compound $\mathbf{1 1}$}

A solution of compound $9(10 \mathrm{mmol})$ in ethanol:water (1:1) was refluxed in the presence of $2 \mathrm{~N} \mathrm{NaOH}$ for $3 \mathrm{~h}$, then, the resulting solution was cooled to room temperature, and acidified to $\mathrm{pH} 4$ with $37 \% \mathrm{HCl}$. The precipitate formed was filtered off, washed with water, and recrystallized from ethyl acetate to afford the desired compound.

\section{5-[(6-Morpholin-4-ylpyridin-3-yl)methyl]-4-phenyl-} 4H-1,2,4-triazole-3-thiol (11)

Yield (3.17 g, $87 \%$ ); m.p. $165-166{ }^{\circ} \mathrm{C}$; IR $\left(\mathrm{KBr}, \mathrm{v}, \mathrm{cm}^{-1}\right)$ : 3,327 (NH), 3,093 (Ar CH), 2,857 (SH), 1,451 (C=N), $1,115(\mathrm{C}-\mathrm{O}) ;{ }^{1} \mathrm{H}$ NMR (DMSO- $\left.d_{6}, \delta \mathrm{ppm}\right): 3.17$ (s, $4 \mathrm{H}, \mathrm{N}-$ $\left.2 \mathrm{CH}_{2}\right), 3.66\left(\mathrm{~s}, \quad 4 \mathrm{H}, \mathrm{O}-2 \mathrm{CH}_{2}\right), 4.06\left(\mathrm{~d}, 2 \mathrm{H}, \mathrm{CH}_{2}\right.$, $J=2.2 \mathrm{~Hz}), 5.51(\mathrm{bs}, 1 \mathrm{H}, \mathrm{NH}), 6.68(\mathrm{~d}, 1 \mathrm{H}, \operatorname{arH}$, $J=6 \mathrm{~Hz}), 6.81(\mathrm{~d}, 1 \mathrm{H}, \operatorname{arH}, J=4.0 \mathrm{~Hz}), 7.44(\mathrm{bs}, 2 \mathrm{H}$, arH), 7.52 (bs, 4H, arH), 13.91 (s, 1H, SH); ${ }^{13} \mathrm{C}$ NMR (DMSO- $d_{6}, \delta$ ppm): $38.90-41.41$ (DMSO- $d_{6}+\mathrm{CH}_{2}$ ), 47.27 $\left(\mathrm{N}-2 \mathrm{CH}_{2}\right), 66.72\left(\mathrm{O}-2 \mathrm{CH}_{2}\right), \operatorname{arC}:[108.81(\mathrm{CH}), 124.04$ $(2 \mathrm{CH}), 128.74(2 \mathrm{CH}), 130.05(2 \mathrm{CH}), 132.70(\mathrm{CH}), 134.16$ (C), 137.63 (C), 151.06 (C)], 153.48 (triazole C-3), 168.73 (triazole C-5); LC-MS: $m / z$ (\%) $368.22[\mathrm{M}]^{+}$(62), 165.45 (80); Anal.calcd (\%) for $\mathrm{C}_{18} \mathrm{H}_{20} \mathrm{~N}_{6} \mathrm{OS}$ : C, 58.68; H, 5.47; N, 22.81, S, 8.70. Found: C, 58.72; H, 5.42; N, 22.80; S, 8.82 .

Synthesis of compound $\mathbf{1 2}$

Concentrated sulfuric acid $(64 \mathrm{mmol})$ was added into compound 9 (10 mmol) drop by drop under stirring, and the reaction content was stirred in an ice bath for $15 \mathrm{~min}$. The mixture was allowed to reach to room temperature and stirred for an additional $3 \mathrm{~h}$. Then, the resulting solution was poured into ice-cold water and made alkaline to $\mathrm{pH} 8$ with ammonia. The precipitated product was filtered, washed with water, and recrystallized from ethanol to afford the desired product. 
5-[(6-Morpholin-4-ylpyridin-3-yl)methyl]-N-phenyl-1,3,4thiadiazol-2-amine (12)

Yield (2.13 g, $58 \%)$; m.p. $172-173{ }^{\circ} \mathrm{C}$; IR $\left(\mathrm{KBr}, v, \mathrm{~cm}^{-1}\right)$ : 3,252 (2NH), 3,077 (Ar CH), 1,599 (C=N), 1,121 (C-O); ${ }^{1} \mathrm{H}$ NMR (DMSO- $d_{6}, \delta$ ppm): 3.49 (bs, $4 \mathrm{H}, \mathrm{N}-2 \mathrm{CH}_{2}$ ), 3.66 (bs, $\left.4 \mathrm{H}, \mathrm{O}-2 \mathrm{CH}_{2}\right), 4.49\left(\mathrm{~s}, 2 \mathrm{H}, \mathrm{CH}_{2}\right), 6.04$ (bs, $1 \mathrm{H}, \mathrm{NH}$ ), 7.26-7.34 (m, 4H, arH), 7.54-7.66 (m, 4H, arH), 10.23 (s,1H, NH); ${ }^{13} \mathrm{C}$ NMR (DMSO- $\left.d_{6}, \delta \mathrm{ppm}\right): 34.63\left(\mathrm{CH}_{2}\right)$, $47.18\left(\mathrm{~N}-2 \mathrm{CH}_{2}\right), 66.69\left(\mathrm{O}-2 \mathrm{CH}_{2}\right)$, arC: [109.13 $(\mathrm{CH})$, $117.93(2 \mathrm{CH}), 122.42(2 \mathrm{CH}), 125.33(\mathrm{CH}), 129.75(2 \mathrm{CH})$, 137.53 (C), 141.31 (C), 153.50 (C)], 161.75 (thiadiazole C-2), 165.11 (thiadiazole C-5); LC-MS: $m / z$ (\%) 368.45 $[\mathrm{M}]^{+}(56), 165.45$ (85); Anal.calcd (\%) for $\mathrm{C}_{18} \mathrm{H}_{20} \mathrm{~N}_{6} \mathrm{OS}$ : C, 58.68; H, 5.47; N, 22.81, S, 8.70. Found: C, 58.74; H, $5.55 ; \mathrm{N}, 22.85 ; \mathrm{S}, 8.75$.

\section{Synthesis of compound $\mathbf{1 3}$}

Ethyl bromoacetate was added to the solution of compound 9 in absolute ethanol $(10 \mathrm{mmol})$, and the mixture was refluxed in the presence of dried sodium acetate $(16.4 \mathrm{~g}$ $200 \mathrm{mmol}$ ) for $9 \mathrm{~h}$. Then, the mixture was cooled to room temperature, poured into ice-cold water under stirring, and left overnight in cold. The formed solid was filtered, washed with water three times, and recrystallized from benzene-petroleum ether (1:2) to afford the pure compound.

2-[(6-Morpholin-4-ylpyridin-3-yl)amino]-N'-(4-oxo-3phenyl-1,3-thiazolidin-2-ylidene)acetohydrazide (13)

Yield (3.33 g, $45 \%)$; m.p. $201-202{ }^{\circ} \mathrm{C}$; IR $\left(\mathrm{KBr}, \mathrm{v}, \mathrm{cm}^{-1}\right)$ : 3,326 (2NH), 1,746 $(2 \mathrm{C}=\mathrm{O}), 1,492(\mathrm{C}=\mathrm{N}), 1,119(\mathrm{C}-\mathrm{O})$; ${ }^{1} \mathrm{H}$ NMR (DMSO- $d_{6}, \delta \mathrm{ppm}$ ): 3.17 (bs, $4 \mathrm{H}, \mathrm{N}-2 \mathrm{CH}_{2}$ ), 3.67 (bs, $\left.4 \mathrm{H}, \mathrm{O}-2 \mathrm{CH}_{2}\right), 3.86\left(\mathrm{~d}, 2 \mathrm{H}, \mathrm{CH}_{2}, J=3.8 \mathrm{~Hz}\right.$ ), 4.18 (s, $\left.2 \mathrm{H}, \mathrm{S}-\mathrm{CH}_{2}\right), 5.74$ (bs, $\left.1 \mathrm{H}, \mathrm{NH}\right), 6.89-7.16(\mathrm{~m}, 5 \mathrm{H}, \mathrm{arH})$, 7.32-7.38 (m, 3H, arH), $10.86(\mathrm{~s}, 1 \mathrm{H}, \mathrm{NH}) ;{ }^{13} \mathrm{C}$ NMR (DMSO- $d_{6}, \delta$ ppm): $30.61\left(\mathrm{NH}-\mathrm{CH}_{2}\right), 45.58$ (thiazolidine$\left.\mathrm{CH}_{2}\right), 56.28\left(\mathrm{~N}-2 \mathrm{CH}_{2}\right), 66.64\left(\mathrm{O}-2 \mathrm{CH}_{2}\right)$, arC: [107.12 $(\mathrm{CH}), 108.79(\mathrm{CH}), 121.52(\mathrm{CH}), 124.15(\mathrm{CH}), 125.19$ $(\mathrm{CH}), 126.52(\mathrm{C}), 129.52(\mathrm{CH}), 130.02(\mathrm{CH}), 132.84(\mathrm{CH})$, 138.32 (C), 148.02 (C)], 152.30 (thiazolidine C-2), 158.39 (thiazolidine C-4), $170.94(\mathrm{C}=\mathrm{O})$; LC-MS: $\mathrm{m} / \mathrm{z}(\%) 426.52$ $[\mathrm{M}]^{+}$(52), 215.86 (64), 165.42 (74); Anal.calcd (\%) for $\mathrm{C}_{20} \mathrm{H}_{22} \mathrm{~N}_{6} \mathrm{O}_{3} \mathrm{~S}: \mathrm{C}, 56.32 ; \mathrm{H}, 5.20 ; \mathrm{N}, 19.70, \mathrm{~S}, 7.52$. Found: C, 56.42; H, 5.32; N, 19.65; S, 7.62.

\section{Antimicrobial activity}

All test microorganisms were obtained from the Hifzissihha Institute of Refik Saydam (Ankara, Turkey) and were as follows: Escherichia coli (E. coli) ATCC35218, Yersinia pseudotuberculosis (Y. pseudotuberculosis) ATCC911, Pseudomonas aeruginosa (P. aeruginosa) ATCC43288, Enterococcus faecalis (E. faecalis) ATCC29212, Staphylococcus aureus (S. aureus) ATCC25923, Bacillus cereus (B. cereus) 709 Roma, Mycobacterium smegmatis (M. smegmatis) ATCC607, Candida albicans (C. albicans) ATCC60193, and Saccharomyces cerevisiae (S. cerevisia) RSKK 251. All the newly synthesized compounds were weighed and dissolved in hexane to prepare extract stock solution of 20.000 microgram/milliliter $(\mu \mathrm{g} / \mathrm{mL})$.

The antimicrobial effects of the substances were tested quantitatively in respective broth media by means of double microdilution, and the minimal inhibition concentration (MIC) values $(\mu \mathrm{g} / \mathrm{mL})$ were determined. The antibacterial and antifungal assays were performed in Mueller-Hinton broth (MH) (Difco, Detroit, MI) at pH.7.3 and buffered Yeast Nitrogen Base (Difco, Detroit, MI) at pH 7.0, respectively. The micro dilution test plates were incubated for $18-24 \mathrm{~h}$ at $35{ }^{\circ} \mathrm{C}$. Brain Heart Infusion broth (BHI) (Difco, Detriot, MI) was used for M. smegmatis, and incubated for $48-72 \mathrm{~h}$ at $35^{\circ} \mathrm{C}$ (Woods et al., 2003). Ampicillin $(10 \mu \mathrm{g})$ and fluconazole $(5 \mu \mathrm{g})$ were used as standard antibacterial and antifungal drugs, respectively. Dimethylsulfoxide with dilution of 1:10 was used as solvent control. The results are presented in Table 1. Urease inhibitory activity was determined according to Van Slyke and Archibald (Van Slyke and Archibald, 1944), and the results are shown in Table 2.

Open Access This article is distributed under the terms of the Creative Commons Attribution License which permits any use, distribution, and reproduction in any medium, provided the original author(s) and the source are credited.

\section{References}

Adil M, Aslama S, Mahmoodb S, Shahidc M, Saeedb A, Iqbala J (2011) Synthesis, biological assay in vitro and molecular docking studies of new Schiff base derivatives as potential urease inhibitors. Eur J Med Chem 46:5473-5479

Aktay G, Tozkoparan B, Ertan M (2009) Investigation of antioxidant properties of some 6-( $\alpha$-aminobenzyl)thiazolo[3,2-b]-1,2,4-triazole-5-ol compounds. J Enzym Inhib Med Chem 24:898-902

Amtul Z, Rahman A, Siddiqui RA, Choudhary MI (2002) Chemistry and mechanism of urease inhibition. Curr Med Chem 9:1323-1348

Amtul Z, Rasheed M, Choudhary MI, Supino R, Khan KM, Rahman A (2004) Kinetics of novel competitive inhibitors of urease enzymes by a focused library of oxadiazoles/thiadiazoles and triazoles. Biochem Biophys Res Commun 319:1053-1057

Andres CJ, Bronson JJ, Andrea SVD, Deshpande MS, Falk PJ, GrantYoung KA, Harte WE, Ho HT, Misco PF, Robertson JG, Stock D, Sun Y, Walsh AW (2000) 4-Thiazolidinones: novel inhibitors of the bacterial enzyme murB. Bioorg Med Chem Lett 10:715-717

Aridoss G, Balasubramanian GAS, Parthiban P, Kabilan S (2007) Synthesis, stereochemistry and antimicrobial evaluation of some $\mathrm{N}$-morpholinoacetyl-2,6-diarylpiperidin-4-ones. Eur J Med Chem 42:851-860 
Ashiralieva A, Kleiner D (2003) Polyhalogenated benzo- and naphthoquinones are potent inhibitors of plant and bacterial ureases. FEBS Lett 555:367-370

Ashok M, Holla BS, Poojary B (2007) Convenient one pot synthesis and antimicrobial evaluation of some new Mannich bases carrying 4-methylthiobenzyl moiety. Eur J Med Chem 42:1095-1101

Bachmeier KL, Williams AE, Warmington JR, Bang SS (2002) Urease activity in microbiologically-induced calcite precipitation. J Biotechnol 93:171-181

Barreca ML, Chimirri A, Luca LD, Monforte A, Monforte P, Rao A, Zappala M, Balzarini J, De Clercq E, Pannecouque C, Witvrouw M (2001) Discovery of 2,3-diaryl-1,3-thiazolidin-4-ones as potent anti-HIV-1 agents. Bioorg Med Chem Lett 11:1793-1796

Bayrak H, Demirbas A, Demirbas N, Alpay Karaoglu S (2009a) Synthesis of some new 1,2,4-triazoles starting from isonicotinic acid hydrazide and evaluation of their antimicrobial activities. Eur J Med Chem 44:4362-4366

Bayrak H, Demirbas A, Alpay Karaoglu S, Demirbas N (2009b) Synthesis of some new 1,2,4-triazoles, their Mannich and Schiff bases and evaluation of their antimicrobial activities. Eur J Med Chem 44:1057-1066

Bayrak H, Demirbas A, Demirbas N, Alpay Karaoglu S (2010a) Cyclization of some carbothioamide derivatives containing antipyrine and triazole moieties and investigation of their antimicrobial activities. Eur J Med Chem 45:4726-4732

Bayrak H, Demirbas A, Bektas H, Alpay Karaoglu S, Demirbas N (2010b) Synthesis and antimicrobial activities of some new 1,2,4-triazole derivatives. Turk J Chem 34:835-846

Bekircan O, Ozen T, Gumrukcuoglu N, Bektas H (2008) Synthesis and antioxidant properties of some new 3-(4-chlorophenyl)-5(pyridin-4-yl)-4H-1,2,4-triazole derivatives. Z Naturforsch 63: $548-554$

Bektas H, Karaali N, Sahin D, Demirbas A, Alpay Karaoglu S, Demirbas N (2010) Synthesis and antimicrobial activities of some new 1,2,4-triazole derivatives. Molecules 15:2427-2438

Bektas H, Demirbas A, Demirbas N, Alpay Karaoglu S (2012) Synthesis and biological activity studies of new hybrid molecules containing tryptamine moiety. Med Chem Res 21:212-223

Bonde CG, Gaikwad NJ (2004) Synthesis and preliminary evaluation of some pyrazine containing thiazolines and thiazolidinones as antimicrobial agents. Bioorg Med Chem 12:2151-2161

Cai S, Li QS, Borchardt RT, Kuczera K, Schowen RL (2007) The antiviral drug ribavirin is a selective inhibitor of S-adenosyl-Lhomocysteine hydrolase from Trypanosoma cruzi. Bioorg Med Chem 15:7281-7287

Capan G, Ulusoy N, Ergenc N, Kiraz M (1999) New 6-phenylimidazo[2,1-b]thiazole derivatives: synthesis and antifungal activity. Monatsh Chem 130:1399-1407

Cheng K, Zheng QZ, Zhu HL (2009) Syntheses, structures and urease inhibitory activities of mononuclear cobalt(III) and 1D cobalt(II) complexes with ligands derived from 3-formylsalicylic acid. Inorg Chem Commun 12:1116-1119

Cobena AS, Misselbrook TH, Arce A, Mingot JI, Diez JA, Vallejo A (2008) An inhibitor of urease activity effectively reduces ammonia emissions from soil treated with urea under Mediterranean conditions. Agric Ecosyst Environ 126:243-249

Cui Y, Dang Y, Yang Y, Zhang S, Ji R (2005) Syntheses and antibacterial activity of a series of 3-(pyridine-3-yl)-2-oxazolidinone. Eur J Med Chem 40:209-214

Das B, Rudra S, Yadav A, Ray A, Rao AVSR, Srinivas ASSV, Saini S, Shukla S, Pandya M, Bhateja P, Malhotra S, Mathur T, Arora SK, Rattan A, Metha A (2005) Synthesis and SAR of novel oxazolidinones: discovery of ranbezolid. Bioorg Med Chem Lett 15:4261-4267

Demirbas A, Sahin D, Demirbas N, Alpay Karaoglu S (2009) Synthesis of some new 1,3,4-thiadiazol-2-ylmethyl-1,2,4- triazole derivatives and investigation of their antimicrobial activities. Eur J Med Chem 44:2896-2903

Dixit PP, Nair PS, Patil VJ, Jain S, Arora SK, Sinha N (2005) Synthesis and antibacterial activity of novel (un)substituted benzotriazolyl oxazolidinone derivatives. Bioorg Med Chem Lett 15:3002-3005

Dixit PP, Patil VJ, Nair PS, Jain S, Sinha N, Arora SK (2006) Synthesis of 1-[3-(4-benzotriazol-1/2-yl-3-fluoro-phenyl)-2-oxooxazolidin-5-ylmethyl]-3-substituted-thiourea derivatives as antituberculosis agents. Eur J Med Chem 41:423-428

Domínguez MJ, Sanmartín C, Font M, Palop JA, Francisco SS, Urrutia O, Houdusse F, Garci ca-Mina J (2008) Design, synthesis, and biological evaluation of phosphoramide derivatives as urease inhibitors. J Agric Food Chem 56:3721-3731

Duruibe JO, Ogwuegbu MOC, Egwurugwu JN (2007) Heavy metal pollution and human biotoxic effects. Int J Phys Sci 2:112-118

Dye C, Phill D (2006) Global epidemiology of tuberculosis. The Lancet 367:938-940

Dye C, Williams BG (2009) Slow elimination of multidrug-resistant tuberculosis. Transl Med 1(3):3-8

El-Gaby MSA, El-Hag Ali GAMA, El-Maghraby A, Abd El-Rahman MT, Helal MHM (2009) Synthesis, characterization and in vitro antimicrobial activity of novel 2-thioxo-4-thiazolidinones and 4,4'-bis(2-thioxo-4-thiazolidinone-3-yl)diphenylsulfones. Eur J Med Chem 44:4148-4152

Gage JG, Perrault WP, Poel TJ, Thomas RC (2000) Stereodivergent synthesis of sulfoxide-containing oxazolidinone antibiotics. Tetrahedron Lett 41:4301-4305

Giera R, Cantos-Llopart C, Amat M, Bosch J, del Castillo JC, Huguet (2006) New potential antibacterials: a synthetic route to $N$ aryloxazolidinone/3-aryltetrahydroisoquinoline hybrids. Bioorg Med Chem Lett 16:529-531

Gupta A, Unadkat JD, Mao Q (2007) Interactions of azole antifungal agents with the human breast cancer resistance protein (BCRP). J Pharm Sci 96:3226-3235

Hancu G, Gaspar A, Gyeresi A (2007) Separation of 1,4-benzodiazepinesby micellar electrokinetic capillary chromatography. J Biochem Biophys Methods 69:251-259

Ito Y, Shibata K, Hongo A, Ecabet KinoshitaM (1998) Sodium, a locally acting antiulcer drug, inhibits urease activity of Helicobacter pylori. Eur J Pharm 345:193-198

Khan KM, Wadood A, Ali M, Ullah Z, Ul-Haq Z, Lodhi MA, Khan M, Perveen S, Choudhary MI (2010a) Identification of potent urease inhibitors via ligand- and structure-based virtual screening and in vitro assays. J Mol Graph Model 28:792-798

Khan I, Ali S, Hameed S, Rama NH, Hussain MT, Wadood A, Uddin R, Ul-Haq Z, Khan A, Ali S, Choudhary MI (2010b) Synthesis, antioxidant activities and urease inhibition of some new 1,2,4-triazole and 1,3,4-thiadiazole derivatives. Eur J Med Chem 45:5200-5207

Koca M, Servi S, Kirilmis C, Ahmedzade M, Kazaz C, Özbek B, Ötük G (2005) Synthesis and antimicrobial activity of some novel derivatives of benzofuran: part 1 . Synthesis and antimicrobial activity of (benzofuran-2yl) (3-phenyl-3-methylcyclobutyl) ketoxime derivatives. Eur J Med Chem 40:1351-1358

Kot M, Zaborska W, Orlinska K (2001) Inhibition of jack bean urease by $N$-(n-butyl)thiophosphorictriamide and $N$-(n-butyl)phosphorictriamide: determination of the inhibition mechanism. J Enzym Inhib Med Chem 16:507-516

Kot M, Karcz W, Zaborska W (2010) 5-Hydroxy-1,4-naphthoquinone (juglone) and 2-hydroxy-1,4-naphthoquinone (lawsone) influence on jack bean urease activity: elucidation of the difference in inhibition activity. Bioorg Chem 38:132-137

Krajewska B (2009) Ureases I. Functional, catalytic and kinetic properties: a review. J Mol Catal B Enzym 59:9-21

Kreybig T, Preussmann R, Schmidt W (1968) Chemical constitution and teratogenic effect in rats. I. Carbonic acid amides, carbonic 
acid hydrazides and hydroxamic acids. Arzneim Forsch 18: 645-657

Küçükgüzel SG, Oruç EE, Rollas S, Şahin F, Özbek A (2002) Synthesis, characterisation and biological activity of novel 4-thiazolidinones, 1,3,4-oxadiazoles and some related compounds. Eur J Med Chem 37:197-206

Matsubara S, Shibata H, Ishikawa F, Yokokura T, Takahashi M, Sugimura T (2003) Suppression of Helicobacter pylori-induced gastritis by green tea extract in Mongolian gerbils. Biochem Biophys Res Commun 310:715-719

Muri EMF, Mishra H, Avery MA, Williamson JS (2003) Design and synthesis of heterocyclic hydroxamic acid derivatives as inhibitors of Helicobacter pylori urease. Synth Commun 33:1977-1995

National Committee for Clinical Laboratory Standard (1999) Methods for determining bactericidal activity of antimicrobial agents, App Guid NCCLS, Willanova, M26-A: 18-19

Panneerselvam P, Nair RR, Vijayalakshimi G, Subramanian EH, Sridhar SK (2005) Synthesis of Schiff bases of 4-(4-aminophenyl)-morpholine as potential antimicrobial agents. Eur J Med Chem 40:225-229

Rao BM, Sangaraju S, Srinivasu MK, Madhavan P, Devi ML, Kumar PR, Candrasekhar P, Arpitha C, Balaji TS (2006) Development and validation of a specific stability indicating high performance liquid chromatographic method for rizatriptan benzoate. J Pharm Biomed Anal 41:1146-1151

Raparti V, Chitre T, Bothara K, Kumar V, Dangre S, Khachane C, Gore S, Deshmane B (2009) Novel 4-(morpholin-4-yl)- $N^{\prime}$ (arylidene)benzohydrazides: synthesis, antimycobacterial activity and QSAR investigations. Eur J Med Chem 44:3954-3960

Sahin D, Bayrak H, Demirbas A, Demirbas N, Alpay-Karaoglu S (2011) Design and synthesis of some azole derivatives as potential antimicrobial agents. Med Chem Res. doi:10.1007/ s00044-012-9992-2

Schiller SD, Fung HB (2007) Posaconazole: an extended-spectrum triazole antifungal agent. Clin Ther 29:1862-1886

Shi DH, You ZL, Xu C, Zhang Q, Zhu HL (2007) Synthesis, crystal structure and urease inhibitory activities of Schiff base metal complexes. Inorg Chem Commun 10:404-406

Shin JE, Kim JM, Bae EA, Hyun YJ, Kim DH (2005) In Vitro Inhibitory Effect of Flavonoids on Growth, Infection and Vacuolation of Helicobacter pylori. Planta Med 71:197-201

Srivastava BK, Jain MR, Solanki M, Soni R, Valani D, Gupta S, Mishra B, Takale V, Kapadnis P (2008) Synthesis and in vitro antibacterial activities of novel oxazolidinones. Eur J Med Chem 43:683-693
Van Slyke DD, Archibald RM (1944) Monometric, titrimetric and colorimetric methods for measurements of urease activity. J Biol Chem 154:623-642

Vicini P, Geronikaki A, Incerti M, Zani F, Dearden J, Hewitt M (2008) 2-Heteroarylimino-5-benzylidene-4-thiazolidinones analogues of 2-thiazolylimino-5-benzylidene-4-thiazolidinones with antimicrobial activity: synthesis and structure-activity relationship. Bioorg Med Chem 16:3714-3724

Weidner-Wells MA, Broggs CM, Foleno BD, Melton J, Bush K, Goldshmidt RM, Hlasta D (2002) Novel piperidinyloxy oxazolidinone antibacterial agents. Diversification of the $N$-substituent. Bioorg Med Chem 10:2345-2351

Woods GL, Brown-Elliott BA, Desmond EP, Hall GS, Heifets L, Pfyffer GE, Ridderhof JC, Wallace RJ, Warren NC, Witebsky FG (2003) Susceptibility testing of mycobacteria, nocardiae, and other aerobic actinomycetes. App Stand NCCLS document M24-A: $18-23$

Wyrzykiewicz E, Wendzonka M, Kedzi B (2006) Synthesis and antimicrobial activity of new (E)-4-[piperidino (4'-methylpiperidino-, morpholino-) $N$-alkoxy]stilbenes. Eur J Med Chem 41: $519-525$

Xiao ZP, Maa TW, Fu WC, Peng XC, Zhang AH, Zhu HL (2010) The synthesis, structure and activity evaluation of pyrogallol and catechol derivatives as Helicobacter pylori urease inhibitors. Eur J Med Chem 45:5064-5070

Yamashita Y, Kawada SZ, Nakaro H (1990) Competitive binding of 7-substituted-2,3-dichlorodibenzo- $p$-dioxins with human placental Ah receptor-A QSAR analysis. Biochem Pharmacol 39: 737-744

You ZL, Zhang L, Shi DH, Wang XL, Li XF, Ma YP (2010) Synthesis, crystal structures and urease inhibitory activity of copper(II) complexes with Schiff bases. Inorg Chem Commun 13:996-998

Yu LT, Ho MT, Chang CY, Yang TK (2007) Asymmetric zincReformatsky reaction of evans chiral imide with acetophenones and its application to the stereoselective synthesis of triazole antifungal agents. Tetrahedron Asymmetry 18:949-962

Zalavadiya P, Tala S, Akbari J, Joshi H (2009) Multi-component synthesis of dihydropyrimidines by iodine catalyst at ambient temperature and in vitro antimycobacterial activity. Arch Pharm 342:469-475

Zheng QZ, Cheng K, Zhang XM, Liu K, Jiao QC, Zhu HL (2010) Synthesis of some $N$-alkyl substituted urea derivatives as antibacterial and antifungal agents. Eur $\mathrm{J}$ Med Chem 45: $3207-3212$ 